\title{
New Viewpoints of Indoor Display Oriented Environment Art Teaching
}

\author{
Jianwei Ban
}

Department of Environmental Art Design, Hebei Institute of Fine Art ,ShiJiaZhuang HeBei, 050700, China

Keywords: indoor display, Teaching, Practice, Innovation, In field

\begin{abstract}
According to the interior design we get the deepening course which named interior furnishings design .In the process of environment art of teaching practice, based on the traditional teaching mode, put indoor display design for the new direction, making the students transform learning of knowledge in classroom into industry skills, create a new method of teaching reform. This paper puts forward some new teaching methods, establish a new teaching method research mechanism, can realize continuous improvement and innovation of indoor display curriculum system , develop the students' comprehensive ability of innovation and practice effectively.
\end{abstract}

\section{Interior Design Professional Teaching}

As the "half" of higher education, higher vocational education of our country starts relatively late, not mature enough in many ways, it's decided to interior design teaching in our country exists some problems that cannot be ignored in terms of talent training, has not yet been fully reflects the higher vocational education and ordinary higher education in personnel training and teaching mode. , to say the higher vocational teaching mode has been imitating the teaching model of normal universities and colleges of undergraduate course, cause problems between talents training and enterprises demand. Specifically, the following a series of problems existing in Chinese interior design in higher vocational colleges teaching:(1) focus too much on 'knowledge of system theory, is to practice teaching, which cause students practical operation ability present situation is not optimistic; (2)in terms of teaching plan, taken from a professional basic course gradually transition to the practice of professional design courses, the connection between the teaching is not quite close together, in the isolated state, leading to keep pace with industry technology update teaching content; (3)training venue, higher vocational colleges for higher vocational students training project is a single, even if can enter the enterprises to carry out field work, but because internship location is scattered, the guidance of the school teachers to guide for each student; The guidance of teachers and enterprise also want to busy work, it is difficult to take care of guidelines for the interns, so caused during the field work of higher vocational students in a state of "sheep". More than a series of problems that in interior design education in higher vocational colleges exists many problems, on the one hand lead to higher vocational students professional ability is insufficient, can't meet the demand of industry development; On the other hand, the market urgently demand for interior design talent, but can't find the ideal talents, both sides suffer. Take the studio system teaching mode can provide powerful way of thinking to solve the above a series of problems.

\section{The Necessity of Indoor Display Professional Direction in Higher Education}

Indoor display design for the emphasis on space design, interface design and decorate indoor space design of indoor physical environment is hard adornment design deepening and the necessary supplement of the content, requires the designer with high aesthetic quality, strong ability of resource integration, and for a variety of indoor environment and display product combination collocation of executive ability. However, currently engaged in the design of indoor display workers tend to be professional environment users and furniture and curtain salesmen, indoor display a grave shortage of professional talents with high qualities [1]. The quickening pace of urbanization in recent years, the rapid development of real estate industry, the requirement of increasing the people's life environment, and after the coming of the era of hardcover, gaps in the field of display 
art design interior design market increasingly apparent. Interior decoration industry, on the other hand, the division of refinement that can accurately grasp market trends, the rapid integration of channel resources, and in indoor display of operation of professional talent demand continues to grow. 2005-2010, the decoration company generally started across the country set up soft outfit, indoor display of the jobs growth is rapid, and professional education lag far cannot satisfy the demand. After industry in the expert argumentation and all aspects of similar colleges and universities, are fully affirmed the fill in the blanks, carry out teaching feasibility and the necessity.

The urgency of the demand for the talents, the art institute of the Chinese women's college in 2004, the first at the undergraduate level opened its interior furnishings design professional direction, then the corresponding other colleges and universities were established to side.

The direction of the course, many industry association and Beijing, Shanghai, Guangdong commercial organizations are specially introduced the indoor display social training, more art colleges and universities graduates are engaged in the design of associated with indoor display, indoor display of the higher education needs to be mature teaching system and teaching methods of the system. Indoor display professional direction in higher education to emphasize the necessity of indoor display design space design, space interface decoration design and indoor physical environment design for indoor hard adornment is the deepening of design content and the necessary supplement, requires the designer with high aesthetic quality, strong ability of resource integration, and for a variety of indoor environment and display product combination collocation of executive ability. However, currently engaged in the design of indoor display workers tend to be professional environment users and furniture and curtain salesmen, indoor display a grave shortage of professional talents with high qualities. The quickening pace of urbanization in recent years, the rapid development of real estate industry, the requirement of increasing the people's life environment, and after the coming of the era of hardcover, gaps in the field of display art design interior design market increasingly apparent. Interior decoration industry division of refinement, on the other hand, can accurately grasp the market dynamics, the rapid integration.

\section{The Indoor Display Characteristics of the Teaching System}

Innovative and Comprehensive. Interior furnishings design as a major direction in our country's higher education industry is a new content. Due to interior design education for many years, however, has been formed a relatively mature pattern, indoor display how to in the traditional mode to complete the new breakthrough, for teachers and students is a huge challenge. Open a new professional direction, not only to better inherit the traditional, based on its innovation. Innovation cannot be imagined, arbitrary, the demand of the industry and the professional division of refinement is teaching the direction. Interior furnishings design courses to teach students to grasp the pulse of the market, cultivate their ability of practical application, satisfy complex market channels for the designer's comprehensive quality requirements. To guide the student to begin from focus on lifestyle, instead of the traditional understanding of interior design pattern mode, through a series of targeted professional guidance to make the students fully understand the market, do a batch of tasting the traditional, grasp modern, forward-looking vision, the ability of comprehensive designer. Therefore, indoor display design curriculum framework must satisfy the application of expression, the artistic quality of training students, manipulation of the comprehensive ability of execution and innovation consciousness.

Provide and Universality. Interior furnishings design compared with the traditional sense of the interior design more deep going and universality, interior design is a kind of stage design, indoor display design is a kind of sustainable design, is to grasp the overall style and theme of depth and throughout the process of people's life. [2] This requires designer not only is the elegant furniture, handicraft in interior space for a simple arrangement, also is not simple modification on the interior of the building. In today's division of professional continuously detailed, indoor display designers to be able to use comprehensive art quality, integrated marketing resources and channels, fast and accurate performance theme and style of the space, and can give space user guide for a long time. In this sense, indoor display has the limited class hours should not be an independent curriculum, as a 
professional direction, we need to build a complete, the teaching system of sustainable development, to meet with the demand of the broad market.

The Practicality and Pertinence. The past single wire surrounding the building space outspread course architecture interior design is difficult to achieve the demand of talent training. Professional direction of the interior furnishings design needs to have roots in the soil of a broader, along the direction of the industry demand growing new branches and leaves, so that they can more quickly and accurately capture the industry characteristics, for different industries output targeted applied talents. Therefore, indoor display of the students who study in the basic knowledge of painting, design, practical ability and aesthetic judgment on basis of the focus of the training. They are not only able to complete the general functional, conceptual design, more to be able to create high quality design in practice in detail. [3] As a result, the whole teaching process should be the principle of theory and practice of parallel, and focus on cultivating the students' practical ability, to make the students under the guide of market demand has the strong ability of scheme and the keen market insight, be able to adapt to the market truly developments of applied talents.

\section{Indoor Display Design Method of Teaching}

For indoor display design curriculum framework, can be divided into four according to the change of teaching method in the implementation stage.

The Space Consciousness into Teaching Method. As indoor display the first teaching stage, spatial awareness into teaching method from the professional basic course of integration emphasizes the comprehensive ability of artistic quality.

First, art design teaching can't be ignored to the cultivation of the basis, so the first stage, the emphasis is on the basis of the professional teaching. The sketch, color, design, composition, drawing, craft art history, introduction to display art, indoor display of integrating style genre and other professional basic knowledge, and in the teaching plan's schedule, content cohesion formed on the integration of the teaching outline, design a set of convenient method, make the students through a series of training courses, step by step, gradually grasp and master the fundamental rules of formal beauty, so as to achieve the aim of improving comprehensive art quality. As in training the sketch color, is not a simple continuation of high school based practice in the traditional model of painting, but the introduction of the concept of, abandoning the reappearance of performance means, to change the mindset and broaden the design concept to guide the student to study for the purpose, thus put first-year students were all in the same starting line, before the entrance is not to show off the capital, the basis of understanding and creativity to make the students fully expressed to realize oneself has entered the stage of university study.

The Space Type Teaching Method Respectively. As indoor display of the second teaching stage, the space types were teaching method from the emphasis on the development of professional ability design skills.

The mastery of the basic ability of decoration and the basic law, also need to cultivate students' ability to the design of the concrete implementation scheme. This ability is also in the industry generally generally lack of interior designers. [4] Therefore, in order to improve the students' practical ability in the teaching, in the second stage of the professional course should focus on to set including furniture design process, ceramic technology, fiber, textile design, floral design, lighting design, computer graphics and indoor display of professional practice courses, as well as the theoretical courses in marketing and space planning. These courses in the space of traditional interior design professional classes compulsory courses, to further expand the indoor display is tasted all kinds of decoration process, gradually highlight the emphasis of the display industry, develop the students' ability of comprehensive thinking and design practice. This part seems more miscellaneous, in fact is the necessary knowledge and professional indoor display characteristic course, on the basis of the first stage between training and the third phase of the integrated design has played a good bridge.

Indoor display art is the creation of science and art, its artistic value reflects the need of science and technology, such as composite materials, production technology conditions for mediation, 
through elaborate art processing, so that the indoor environment form a unified and harmonious organism, give a person with beautiful enjoyment. [5] Therefore, at this stage of teaching, the course is more of a variety of materials research. In textile, ceramic, wood, metal, glass, plastic and other composite materials laboratory, with emphasis on the basis, appropriate USES "field type" mode of teaching, by the different material technology and artistic means of teachers' team and lead the students in the laboratory to complete laboratory design project, students according to the project request to choose material and process to complete the design and production, every teacher and laboratory technician for the design of the students provide the most direct guidance and help. Outside class, the laboratory should be fully open to all students, teachers through the scientific research project contracting and social missions of artistic creation, also can let students participate, practice their learning outcomes in courses. In this way of teaching, has broken the old teacher and pupil relationship between teachers and students, students not only learn from teachers design train of thought, process technique and construction procedure, at the same time, teachers also in the creation of the students to get inspired, even lets the student in the best ideas to become reality in the engineering project, these gains are unmatched by traditional classroom teaching. In addition, let students of different grades in the laboratory to complete their design task, which can make students to maximize the use of experimental resources, on the other hand, the communication between each grade students also further strengthen, preach, and to help and take action to the utmost.

Display the art of marketing course arrangement at this stage, students learn by the theory of class and extracurricular market research, to learn market research approach, grasp the market demand of different kinds of space, exercise the ability to communicate with the customers. Such content through professional training curriculum, lets the student in learning professional constantly into the market at the same time, the analysis of industry popular what, what need to integrate, exercise keen ability to capture and filter, fully grasp the popular trend of indoor display market, in order to display the design, production, when the choice of the location accurate, timely and industry standards, strengthen the pertinence and practicability of display design.

The Spatial Relationship Integration Teaching Method. As the third stage of teaching of indoor display, spatial relationship integration teaching method from the innovation and practice ability of strengthen the emphasis on practical case handling ability.

In order to make the innovation ability of students is increased significantly, enhancing classroom teaching practice, interior space design basis shall be subject course and indoor display design in field of the integration of two series as the focus of the third stage of teaching practice, and professional training on a regular basis, to the cultivation of practical ability through two, three years of teaching.

Interior space design project is the necessary way to master of interior design basic common sense, to make the students familiar with the household, commercial, office, catering, entertainment, display and so on various types of space of design principle and application of comprehensive measures to be able to skillfully use performance design. Interior furnishings design field courses specifically for a certain space to display the theme of the style of form a complete set of design, production process and custom pendulum field to carry on the comprehensive training, expand the second phase of the students cognitive range of some process materials, make them in composite materials (including ceramics, fiber, textile, wood, plastic, metal, glass, etc.) in the selection and design on collocation, further improve the decoration language power of expression, and have the opportunity to place their design and production of series display accept the inspection from the overall environment in the real environment. In these two projects, the students through the design for the display of space form the display environment and display, make indoor display space to form a perfect, harmonious and organic environment full of artistic breath.

Teaching team needs and at the same time a large number of indoor decoration engineering company, display art design company, display makers are institutions such as the internship agreement, establishing practice base, in each course before, during and after the three stages of the enterprise's well-known designers, industry experts and successive graduates "please come in", undertake to the student the popularity of industry knowledge, experience sharing, the guidance of 
the design, modification, and evaluation of class assignments, simulation design company set tasks under pressure. At the end of each project of professional training, also want to allow students to "go out", through the cooperation with practice base, let the students to participate in the design and construction link, develop the students' ability of professional practice in real cases.

Can say, in these two projects, the classroom is in the market, the market is the classroom, the students must fully understand the market needs, and their design must be market really need.

Space Creative Freedom Teaching Method. As the fourth teaching stage, indoor display space of creative freedom teaching method and practice from the independent innovation ability promotes emphasis on innovative thinking ability.

Graduation design is to strengthen and perfect the last link of undergraduate learning phase. In the stage of graduation design and thesis, is actually a final integration of several years professional learning and practice. To cultivate students' comprehensive use before the three stages of teaching professional basic theory, basic knowledge and skills, students are required to within a certain topic and the limited space for the display of relatively free design creation, let the students learn to apply any design means to develop indoor display series products, and able to work from conception to production, simulated field to perfect the concept of interpretation. Active use of divergent thinking and convergent thinking, dialectical thinking and critical thinking, and varied the thinking mode of learning, let students take the initiative to explore, to acquire knowledge of subject dynamic role play to the largest, students participate in analysis and problem solving skills to effectively exercise and cultivate, in order to realize the purpose of their major.

Graduation design students to abandon the past passive thinking with the task of learning habits, to know his own self, at the beginning of the conception of digging their excitement in the artistic creation, blatantly in the way they want to express. Then through the graduation design task requirements of strict and rigorous orderly program management, according to each student's personal characteristics and inspiration, help students to develop a scientific and rational choice planning further guidance. Assessment of the final design works by each student works show the space layout and effect of the control and inspection system design ability, i.e. to display space and series display innovative ability and practical operating ability of execution. Purpose is to let students by focusing on high strength training, completely release the artistic potential, inspire creative enthusiasm, integration of exercise ability, in full working condition for jobs.

Indoor display professional should not only meet the needs of the development of industry, to walk in front of the industry will be able to let the students with greater competitiveness in employment. So for indoor display market trends and developments at home and abroad of accurately is the key in the process of teaching. Each professional course assignments are reflected in the students are required to work design connotation at the same time, but also give full consideration to its adaptability to social development and people life style and forward-looking. In addition, students should not only learn knowledge, to master their own fate, but also focus on society, focus on the sustainable development of human society in the design practice. Indoor display professional training of the students are environmental design workers, more should have consciousness of environmental protection and green design. Of all the professional basic course and compulsory courses and elective course teaching process, teachers always want to environmental protection and sustainable development of social responsibility to infiltrate the teaching contents, guides the student to form the consciousness of green design in the osmosis.

\section{Interior Design Professionally some Countermeasures for Constructing the Studio System Teaching Mode}

Analysis the Teaching Goal Carefully. The teaching goal is the basis of practice teaching implementation interior design CAD project, therefore, before the implementation of project practice teaching teachers should make careful analysis for the teaching goal. For example, through the implementation of the project practice teaching to make the students to have a basic understanding of CAD software, mastering and using CAD drawing skills and methods, to improve students' ability to use what they have learned to solve practical problems, etc. When determine 
project practice teaching target, teaching is not only beneficial to the project design, and lay a good foundation to improve the teaching quality of project.

The Reasonable Design of the Content of the Project. Interior design CAD project implementation is the key to ensure the rationality of the content of the project, to some extent, the success of the project teaching method implementation, therefore, the practice of teaching teachers should cause enough attention. For example, to help students master CAD skills, teachers can design requires students to draw some interior design: first, the whole project is divided into different tasks, such as a task, complete plan of interior design drawing; Task completed, elevation drawing; Three, task profile drawing. And according to the practical teaching goal will be subdivided again, different tasks such as floor plan a task can be divided into the wall of the drawing; Windows and doors hole drawing; The stairs, the steps of drawing, etc., to ensure the successful completion of the project tasks, the teacher may according to the reasonable arrangement of task content and complexity of class time. In short, analyze the content of the project is not hard to find, the whole project is divided into different tasks, difficulty since the childhood, the progressive teaching content can greatly decrease the difficulty of students accept CAD teaching efficiency.

Using a Variety of Teaching Methods. Effective development of interior design CAD project practice teaching, inseparable from the effective teaching method of the support, so the teacher should combine the project content and the teaching practice, adopt flexible and varied teaching methods. Project practice teaching, for example, when the question type teaching, teachers can use discussion-based teaching methods and heuristic didactics, help students to understand the emphasis and difficulty of project implementation. At the same time, encourage students to thinking, strengthen the cooperation between the students, together to complete the project assigned by the teacher.

Reasonable Design Project Evaluation Scheme. Interior design CAD project practice teaching process, teachers should design reasonable evaluation scheme, on the one hand, by understanding project practice teaching effect evaluation, optimization and improvement in the teaching practice, to improve the quality of project practice teaching. Ensure project assessment, on the other hand, the rationality of the design, can be objective to evaluate the situation of students to complete the project, to help students fully understand to complete the project in the process of their own weaknesses, spur consolidation under the students in class. For example, the teacher may according to the project implementation, evaluation, teachers' comprehensive evaluation and curriculum design students total scale, to ensure the rationality of the evaluation and fairness.

Pay Attention to the Improvement of Teachers' comprehensive Quality. Studies show that interior design CAD project practice teaching in the teachers' comprehensive quality will have an immediate impact to the project practice teaching results, therefore, interior design CAD project practice teaching teachers should focus on improving their comprehensive quality, on the one hand, combined with their own teaching practice, constantly reflect on problems existing in the project practice teaching, and actively consult experienced teachers and learn the effective project practice teaching skills and methods. Available, on the other hand, teachers should strengthen the study, especially the Internet access to the knowledge of the project practice teaching, and applied to the interior design teaching practice, constantly improve the project practice teaching quality and level.

The Establishment of Curriculum System Based on Interior Design Wwork Process. Teaching mode is the main carrier of the studio system in the working process of the study, in order to make an organic combination of theory and practice, so was established based on the indoor design and working process of curriculum system is very important. Interior design professional when set up the course in higher vocational colleges, the first to enter the market in-depth investigation and analysis, on this basis, find the direction of the curriculum system reform, to sum up the professional typical task as the main target, around professional growth pattern, planning for the students learning areas, and focus on the students' ability training, adhere to the principle of sustainable development, building a scientific and reasonable curriculum system, targeted. In determining, based on the working process of the interior design curriculum system in higher 
vocational colleges should organize industry association, outstanding enterprises, jointly set up a line of teachers curriculum development team, to develop professional core courses. In the development course, to cultivate the students' vocational ability as the main line, to interior design projects as the carrier, in accordance with the ministry of Labour and social security regulations of the state's assistant interior designers professional qualification standards of curriculum standard, as well as combined with social enterprise stipulated by the technical standards, to build up perfect and effective evaluation system.

Set up ZhuanJian Combination of "Double Type" Teachers. To successfully implement the studio system teaching mode, cannot leave the role of teachers. First of all, in order to strengthen the practice ability of school full-time teachers, as a full time teacher in interior design professional teaching must have industry enterprise of actual combat experience, can independently bear university-enterprise cooperation studio project. In higher vocational colleges should also actively encourage teacher credentials the exercise in social enterprises, drive course by actual project development, guide teacher credentials the enterprise's actual project will be imported into the classroom teaching, and students together to complete the project design, it can realize the state of "so". Schools should also encourage the full-time teachers for higher degree, accept the advanced theory study of the forefront of technology, improve the comprehensive quality, set the example demonstration role for the students. Second, the higher vocational colleges should also for part-time teachers to establish a scientific and reasonable access system. Provisions of part-time teachers must have 5 to 8 years of experience in professional practice, has the professional qualification certificate issued by the state, and has more than 2 years engaged in part-time teaching experience, skilled application of educational technology in order to make use of teaching wisdom to guide students in the classroom teaching. In addition, part-time teachers also have good social sense of responsibility and professional ethics quality, set up the leadership for the students. After a semester of the trial, through examination, by the university-enterprise cooperation center to sign long-term employment agreement, to obey the introduction to "off". In order to better play to the role of the part-time teachers, school should encourage them to bold innovation teaching way, open resource sharing platform for part-time teachers, based on university-enterprise cooperation studio, the part-time teachers teaching theory and teaching method of training, but also attract them to actively participate in curriculum development and application of construction, the school subject, participate in the teaching work, etc.

The Implementation of the Studio System Training Mode. First of all, higher vocational colleges have to together organically integrate advantageous resources, realize the university-enterprise cooperation. Practice has proved that through the enterprise in the school, the school into the way of enterprises, the establishment of teaching practice, vocational qualification training, professional and technical services in a studio, is to explore work-integrated learning mode, with industry enterprises to achieve seamless docking, solve problem of current interior design professionals are difficult to adapt to market demand of effective path. Higher vocational colleges through the actual investigation, choose the larger, better efficiency, driving ability is strong, and have strong market competitiveness of industry leading companies as partners. , head of the enterprise is willing to take the initiative to undertake the task of studio teaching, the development course. To sign the agreement of cooperation in running schools between colleges and enterprises set up include interior design jobs in different capability requirements of different types of studio, and arrange for different projects, complete the teaching goal. Second, the interior design studio to introduce close to the requirements of the industry project. One is the industry designer and engineer involved in interior design teaching, they are in the process of teaching naturally reflects the social demand; The second is to strengthen the studio multilateral cooperation to social actual project instead of part of the professional course assignments, make the students directly involved in the actual project design; Three is the studio to undertake a variety of design task, the teacher and students play a wisdom together, common to complete the task, in this process, teachers and students will spark of wisdom, brainstorming, to breathe new life into the classroom teaching. 
Reforming Evaluation System. In order to better promote the studio system, teaching mode, also need to constantly reform the evaluation system, the comprehensive and dynamic to highlight the inspection process. The key is to strengthen enterprise evaluation standard to assess studio quality to perform the job, reveal the studio teachers in the position and function in the process of evaluation, and strengthen team member's mutual, self-assessment, etc., improve the students' ability of independent evaluation. Specifically, the evaluation process around a series of link: on completion of each of the learning situation, students are required to submit work within the given time, including the work plan, the design report and PPT electronic documents, etc. Teachers should actively adopt process inspection ways of evaluation, will every learning situations as an evaluation unit, focus on evaluation of the students' professional skills and professional quality. Students' professional skills include these aspects: indoor design novel and unique; In the process of group discussion to clear language, way of thinking; Active task on; Skilled design document; PPT to make the sound and movement. The students' professional quality includes: discipline, respect teachers; Serious working attitude is rigorous; Clear when communicating with others; Get along well with others. Professional skills to occupy the whole of examination unit $60 \%$ of the total score, professional quality assessment account for $40 \%$. Two parts of the inspection to the studio teacher evaluation, teacher evaluation, group evaluation combine together, makes every effort to get the most comprehensive assessment results. Of course, in view of the assessment results and establish reward system, if the students enter the studio design works, to issue testimonials, offer certain material rewards, in order to meet the students' learning achievement, encourage them to continue.

\section{Conclusion}

Indoor display in the direction of teaching in environmental art professional teaching system has a distinct characteristic, cause the extensive concern of the relevant institutions and research institutions. The cultivation of student's innovation ability and social practice ability has also been widely recognized in the industry, and by constructing the teaching system of innovation, featured by system effective teaching method, can for the social many institutions of higher learning in the decoration company and sales company in the field of indoor display conveying applied interior furnishings design professionals, indoor display will become another hot after the interior design industry.

\section{References}

[1] Ma Jian-mei. Environmental art course teaching mode reform of professional landscape design [J]. Anhui Agricultural Science. 2011 (31)

[2] Tang Jun. The development of modern landscape design present situation and trend analysis [J]. Chinese Gardening Abstract. 2012 (9) : 97-2012.

[3] Han Yu. Experience type teaching, the landscape design course teaching practice research [D]. Nanjing: Nanjing College of Art. 2012

[4] Xiang Xiaoxiao. Environmental art professional teaching reform of landscape design study [J]. Journal of Nanchang Institute of Education. 2013 (4)

[5] liu Chun-bo . Analyses of landscape environmental art [J]. The Young Writer. 2010 (18) 